\title{
AFRICA AND THE NEW INTERNATIONAL ECONOMIC ORDER
}

\author{
By ZDENEK ČervenKa
}

\section{The Organization of African Unity and economic co-operation in Africa}

One of the most interesting features of the OAU was its development into an organization of an exclusive political character. Throughout its existence OAU has been dealing primarily with two sets of political problems, namely

a) decolonization and the liquidation of the white minority rule in Southern Africa;

b) political crisis some of which posed a threat to the very existence of the OAU, such as the Rhodesian Unilateral Declaration of Independence (UDI), or the civil war in Angola.

The political issues have always consumed most of the time of both the Council of Ministers and the Assembly of the Head of Government thus leaving little or no time for the economic problems.

The small place occupied by economic problems in the OAU affairs sharply contrasts with Africa's position as the wealthiest continent of the world with mineral and natural resources which until now were not even fully explored. It also contradicts the emphasis put on the OAU's responsibilities for the economic development of Africa in the OAU Charter and professed by its founding fathers. The Preamble of the OAU Charter speaks of the responsibility to harness the natural and human resources of the continent of Africa for the total advancement of African peoples in spheres of human endeavour. The economic co-operation between the members of the OAU was also given prominence in the purposes of the Charter listed in Article II which includes a duty on part of the OAU members to

1. co-ordinate and intensify their co-operation and efforts to achieve a better life for the peoples of Africa,

2. to promote international co-operation, having due regard to the Charter of the United Nations,

3. co-operation in the field of transport, communications, health, sanitation, nutrition, as well as science and technology.

In this connection it should be recalled that the majority of the founding fathers of the OAU in 1963 really believed that African unity can be achieved only through economic co-operation. Sir Abubakar Tafewa Balewa, Prime Minister of Nigeria, explained it as "practical steps in economic, scientific and cultural cooperation". Much confidence was, at that time put into a regional economic groupings called by President Nyerere of Tanzania "stepping stones towards African Unity". "I should like to lay special emphasis on the importance of economic co-operation as an approach to African unity" said the President of Gabon, Leon Mba, and he expressed a hope that "Realism and efficiency will prevail over passion and precipitance". The concept of African Unity as a "political kingdom" to be attained through a Continental Government of Africa advocated by President Nkrumah of Ghana was rejected as utterly unrealistic. 
Time has shown that while the kind of African political unity envisaged by Dr. Nkrumah is indeed still very far away, the economic unity of Africa is by no means any closer. The transformation of OAU into a political organisation which survived only due to the political unity of its members on decolonization and apartheid indicates that only the broadening of this unity into a true political alliance can bring about also the economic unity of the continent, not the other way round. The Economic and Social Commission of the OAU which held its first session at Niamey in December 1963 was considered by many to be "the most important branch of the Organization of African Unity, in fact the catalyst which will give meaning to African unity" to use the words of the editor of the first issue of OAU Review, Gedamu Abraha, published in May 1964. The lull of almost five years between the first and the second meeting of the OAU Economic and Social Commission during which economic affairs of Africa were handled exclusively by ECA made the specialised commission OAU's sleeping institution.

\section{EAC-experiment in integration which did not work}

This has been exemplarily manifested by the failure of the East African Economic Community which was generally regarded as the most successful regional economic organisation in Africa. The East African Community (EAC) was established by the Treaty for East African co-operation signed by Kenya, Tanzania and Uganda on 6 June 1967. It entered force on 1 December 1967. The objectives of EAC were, inter alia, the following:

Strengthening and regulation of industrial, commercial and other relations of the Partner States, establishment of common Customs and excise tariffs and abolition of restrictions in inter-Partner State trade, introduction of long-term agricultural policy, establishment of an East African Development Bank, harmonization of monetary policies and co-ordination of economic planning and transport policies ${ }^{\text {1" }}$ Despite the high hopes that were raised by the Treaty (and indeed negotiations for the membership of Zambia, Ethiopia, Burundi and Somali were begun), the record of the Community was disheartening. Each country put its own national self interest first and by seeking individual advantage it has eroded the common aims of the community. But the most serious problem was the divergent policies of the Partner States. The Treaty was signed when each of the States was roughly following the same economic policies based on capitalist system of economy. Today the free enterprise that lie at heart of the Treaty no longer exists universally. Tanzania's orientation towards socialist pattern of economic development and its leaning on the Chinese assistance was one major source of tension. When President Milton Obote of Uganda, who was increasingly being influenced by Tanzanian policies was overthrown by general Idi Amin in 1971 and found refuge in Tanzania, the relations between Tanzania and Uganda reached the point of open hostility

\footnotetext{
1 The text of the Treaty was published by the East African Common Services Organisation and was reproduced for example in Basic Documents on African Affairs edited by Ian Brownlies, London: Oxford University Press, 1971. For an historical background and the institutions of the Community see Ingrid D. di Delupis, The East African Community and Common Market, Stockholm: Norstedt and Söners, 1969. For an excellent documentary on the attempts of integration in East Africa see Donald Rotchild, Politics of Integration, Nairobi: East African Publishing House, 1968. For a general information see A handbook of the EAC, published by the Information Division of EAC in Nairobi in 1972.
} 
and never since were truly normalized. This in turn dealt a paralysing blow to the Community in which each of the three Heads of member States can veto any proposal under the Community system.

Since 1974 Tanzania political and economic interests began to shift southwards, in particular towards Mozambique, while the press of Tanzania and Kenya was waging war of words blaming each other for trying to wreck the EAC. By 1975 even the oldest institutions inherited from the British namely the East African Harbours Corporation, the East African Railways Corporation and the East African Posts and Telecommunications totally broke down with each party being convinced that the other was at fault.

In 1976 the split passed the point of no return and the Review Commission set up by the three member States to look into the Treaty was in effect presiding over the Community's dissolution ${ }^{2}$.

The other regional organisations such as the Central African Customs and Economic Union (UDEAC) ${ }^{3}$, The Economic Community of West African States (ECOWAS) ${ }^{4}$ or the Lake Chad Basin Commission (LCBC) $)^{5}$ while spared of similar dramatic show-downs which plagued the EAC could hardly be credited with "bringing about the economic unity of Africa". This is even more true about the economic regional organisation with political overtones such as Organisation commune africaine, malagache et mauritienne (OCAM) workings of which, not free from dissent among its members, were often directed against the common interest of Africa ${ }^{6}$.

Compared with the progress made by the OAU on decolonization and with the success of its international campaign against apartheid which brought the chief offender, the Republic of South Africa, to the brink of expulsion from the United

2 See for example P. G. Okoth, East Africa's Rail Chaos In: African Development, Vol. 9, No. 5, May 1975 and A. Rake, "East African Community splits apart", in the November issue (No. 11) 1975 of the same magazine. "Harbours in a mess" is the title of an article in the Weekly Review, Nairobi, December 8, 1975, which regularly covers the development in EAC. Another example is a study by Al-Noor Kassum, East African Minister for Finance and Administration in its issue of December 1, 1975 entitled "What has the Community achieved?"

3 UDEAC was established on 8 December 1964 at Brazzaville. Its members are the Central African Republic, Cameroon, Gabon and the People's Republic of the Congo. Objectives and institutional structure are described in the Directory of Intergovernmental Co-operation Organisations, published by EAC in 1972.

4 A treaty inaugurating the Economic Community of West African States comprising Ghana, Nigeria, Niger, Togo, Benin (formerly Dahomey), Gambia, Guinea, Liberia, Sierra Leone, Guinea-Bissau, Mali, Mauretania, Senegal, Upper Volta, Ivory Coast was signed in Lagos on 28 May 1975.

The basic aim of the Community was described in the final communiqué of the Heads of State and Government of the 15 members as "promotion of co-operation and development in all fields of economic activity". The closure of the border between Togo and the People's Republic of Benin on 19 October $1975^{\circ}$ when Benin accused Togo of involvement in a plot to overthrow the Government of Lt. Col. Kerekou. The incident aquired a wider proportion as the closure of the border of a number of Ghanian trucks on their way to Lagos. Describing the incident West Africa of 15 December 1975 described it as "Making mock of West African Unity".

5 Established on 22 May 1964 by a treaty between Cameroon, Chad, Niger and Nigeria to regulate the exploitation of water in the Lake Basin countries.

6 The Charter of OCAM was adopted on 27 June 1966 at Tananarive to replace the African and The Charter of OCAM was adopted on 27 June 1966 at Tananarive to replace the African and
Malagasy Union (UAM) of 1961 dissolved under the OAU pressure as not being compatible with the consensus reached in Addis Ababa in May 1963 that all political groupings in Africa should cease to exist in view of the adoption of the OAU Charter. For the UAM-OAU confrontation see author's book Organization of African Unity and Its Charter, London: Ch. Hurst, 1969.

The text of the OCAM Charter can be found for example in Basic Documents of African Regional Organisation, edited by Lois B. Sohn, New York: Oceana Publications, 1971, Vol. 1.

At the OCAM Summit in Bangui in August 1974 the outgoing Secretary General Falilou Kane of Senegal gave a long list of OCAM's economic failures. "It had", he said, "been impossible to set up industries on a regional basis through lack of funds for feasibility projects. A plan to set up on OCAM shipping company had failed because of pressure from traditional shipping groups. Nothing had come of a project to control meat production because members could not agree on where the controlling body should be based. An insurance project had also failed because of pressure from a friendly foreign Power (meaning France).

The sharpest criticism of OCAM came from the Government of Togo calling for the disappearence of OCAM in place of "less political and more technical organisation". The stormy relationships between OCAM members are best illustrated by the constant change of its membership. Mauretania, Zaire, Congo, Chad and Madagascar withdrew from OCAM (though all except for Madagascar remain in its specialized institutions). 
Nations, the performance of the OAU in the economic field had been very disappointing.

However, it would be unfair to criticize OAU for its failure to bring about a substantial improvement in the economic situation of Africa without mentioning two obstacles which stood in the way of the inter-African co-operation at the time when OAU was established. The major was the state of affairs of the African economy, the minor the rivalry between OAU and the United Nations Economic Commission for Africa, ECA?

The magnitude of the economic difficulties faced by independent Africa had been sufficiently illustrated by numbers of studies and analyses published by the Economic Commission for Africa ${ }^{3}$. Among the main constraints on the economic development of Africa at least the following should be mentioned:

1. Slow growth of GNP;

2. Orientation on one commodity;

3. Small size of African economies;

4. The backwardness of African agriculture;

5. Lack of proper inter-African infrastructure;

6. Dependence on the ex-colonial powers ${ }^{9}$.

7 The Economic Commission for Africa was established by resolution 671 A (XXV) of the Economic and Social Council of the United Nations on 29 April 1958 which also defines its terms of reference. These were subsequently amended by resolution 974 D (XXVI) of 5 July 1963 and by resolution 1343 (XLV) of 18 July 1968. The tasks of ECA "acting within the framework of the policies of the United Nations and subject to the general supervision of the Economic and Social Council" were stated to be as follows:

1. Initiate and participate in measures for facilitating concerted action for the economic development of Africa, including its social aspects, with a view to raising the level of economic activity and levels of living in Africa, and for maintaining and strengthening the economic relations of countries and territories of Africa, both among themselves and with other countries of the world;

2. Make or sponsor such investigations and studies of economic and technological problems and developments within the territories of Africa;

3. Undertake or sponsor the collection, evaluation and dissemination of such economic, technological and statistical information:

4. Perform such advisory services as the countries and territories of the region may desire;

5. Assist the Economic and Social Council of the United Nations in discharging its functions within Africa in connexion with economic problems, and problems of technical assistance;

6. Assist in the formulation and development of co-ordinated policies as a basis for practical action in promoting economic and technological development in Africa.

The work of ECA was described or rather dismissed by James S. Maggee in "ECA and the Paradox of African Co-operation", in International Conciliation No. 580, November 1970, New York. It touches also on the relationship between ECA and OAU.

8 Examples of the economic situation in Africa at the time of the establishment of OAU can be found in "A Survey of Economic Conditions in Africa 1960-1964" E/CN. 14/397 of 9 May 1967. The recent facts and in "Economic Bulletin for Africa" published by the United Nations in New York.

9 An excellent book illustrating the ties of former French colonies with France see E. M. Corbett, The French Presence in Black Africa. Washington: Black Orpheus Press, 1972.

10 In 1972, five years of relentness drought had brought catastrophe to almost 25 million people living in the sub-Saharan region of West Africa, known as the Sahel.

Seven countries have been most affected by the drought - Chad, the Gambia, Mali, Mauritania, Niger, Senegal and Upper Volta. These countries cover a geographical area of close to fice and a half million square kilometres with a total population of about 23.6 million, of which over 6 million live in the Sudano-Sahelian region. Some 90 per cent of the population make their living from the land as sedentary farmers or nomadic herdsmen. The land-locked states of Chad, Mali, Niger and Upper Volta are among the least developed in the world, having a per capita GNP level of $\$ 100$ per annum or less.

For more information see Sahelian Newsletter published by UN Centre for Economic and Social Information and the Special Sahelian Office (established in Ougadougou) Document ST/SSO Series A/6. Failures of International Relief in the Sahel area are analysed by Hal Street and Roger Morris in the book Disaster in the Desert, New York, Carneigie Endowment for International Peace, 1974.

$11 \mathrm{E} / \mathrm{CN}$. 14/L. 170 of 1 March 1963 "Draft Report of the Fifth Session to the Economic and Social Council".

12 The inaugural meeting of the Board of Governors of the African Development Bank was held in Lagos from 3 to 7 November 1964. 


\section{Relations between the OAU and ECA}

ECA's attitude towards the new African organisation which was expected to emerge from the meeting of the Heads of State and Government of Independent African States convened to Addis Ababa in May 1963 was most sympathetic. At the 5th meeting at Kinshasa in February 1963 ECA extended its good wishes to the Addis Ababa Conference ${ }^{13}$. ECA also demonstrated its willingness to offer the Conference its assistance by submitting to it a paper entitled "Approaches to African economic integration: Towards co-operation in economic planning and an African Common Market ${ }^{14}$."

However, the relationship between the OAU and ECA soon had assumed a character of a competition rather than co-operation. ECA's monopoly in dealing with African economic problems is apparent from the perusal of the OAU resolutions adopted in the course of its first four years, of which only three touched the economic issue ${ }^{15}$.

The turn for the better came in 1967 when the Council of Ministers of the OAU had set up a plenary committee (Committee "C") within the Council, which considered reports on various aspects of economic and social development submitted to the Council by the Administrative Secretary General. In this way the OAU Secretariat managed to sustain the interest of the Council of Ministers in economic and social affairs and provided each of its sessions with so called "economic balance sheets" on the basis of which recommentations on guidelines of OAU's policy on economic development could be made.

The preoccupation of the OAU with the economic matters was continued in 1968 during which the OAU General Secretariat paid great attention to the preparation for the Second United Nations Trade and Development Conference (UNCTAD II). Unlike in 1964, when UNCTAD I received only little attention of a three paragraph long resolution, OAU embarked on thorough preparation of its members. The most important event in this respect was the meeting of 31 African countries in Algiers from 7 to 15 October 1967 which adopted the "African Declaration of Algiers" endorsed by the ministerial meeting of the non-aligned countries which also met at Algiers and submitted to the UNCTAD II held in New Delhi from 1 February to 29 March $1968^{21}$. The OAU Summit meeting held at Algiers in September 1968 made a further step towards strengthening OAU's role in African

13 ECA adopted a resolution, 75 (V), at its 96th Plenary Meeting on 28 February 1963 on ${ }^{\alpha}$ Conference of Heads of State in Addis Ababa" (E/CN. 14/Res. 75 (V) 1963) commending the initiative for convening such a conference meeting the urgent need for unity and strengthening of African solidarity.

14 This paper was subsequently elaborated by Dr. Chukaka Okonjo of Ibadan University, ECA's Regional Planning Advisor into a study "Economic Unity through Co-ordinated Development in Africa" whose revised version was published as an ECA Document, E/CN. 14/239 Part B, on 13 January 1964.

15 CM/Res. 26 (II) and CM/Res. $43^{\circ}$ (III) on “UN World Trade Conference” adopted in Lagos 1964, and the other one in Cairo 1964 and Resolution on Economic Problems (CM/Res. 98 VIII) in Addis Ababa in 1967 which was the first acknowledgement of OAU Secretariat's efforts at getting OAU involved into African economics.

16 UN Document A/6174 of December 16, 1965.

17 Resolution on the relationship between the ECA and the OAU CM/Res. 72 (V).

18 Resolution CM/Res. 98 (VIII) adopted on 4 March 1967 at the Eight Ordinary Session of the Council at Addis Ababa endorsed Diallo Telli's report on African Economic Co-operation (Doc. CM/ 148).

$19 \mathrm{CM} /$ Res. 123 (IX).

20 This is how the postponement of action on an African common market was justified by an ECA resolution adopted in 1963 (E/CN. 14/RES/86 [V]).

21 The Declaration contains the recommendations of the African countries on the various questions on the agenda of UNCTAD II. It subsequently became a basis of the joint OAU/ECA "Africa's Strategy for Development in the 1970s". The text of the "African Declaration of Algiers" was published by ECA (Doc. E/CN. 14/UNCTAD II/PM. 2/Rev. 2). 
economic development by recognizing that "the economic integration of the African continent constitutes an essential prerequisite for the realization of the aspirations of the OAU22."

The decisive change in the relationship between the OAU and ECA took place on ECA's own grounds - at the United Nations in 1969. It was the making of the "African group" at the United Nations composed of the Heads of African Missions to the United Nations which grew into a new force. Its influence was reflected by the more resolute stand taken by the UN General Assembly on colonialism and apartheid policy of South Africa as well as on the UN economy policy centered at the UN Social and Economic Council. The Africans were asking for a more decisive part in the formulation of the UN economic policy on Africa pointing out a successful performance for the Economic and Social Council's organization in Africa - ECA. They also demanded that ECA was to be compelled to take into consideration OAU's view of all its plans and projects. The word was "co-operation" but its essence was that OAU was to become a partner with the political (and stronger) voice.

The acceptance of OAU's primary responsibility for co-operation between African States in terms of Article II of the OAU Charter was recognized by the ECA at its Ninth Session held in February 1969 in Addis Ababa. In a resolution on "Relations with the Organization of African Unity"3" ECA recognized that the decisions by the Assembly of Heads of State and Government of the OAU is the highest body for the "encouragement and orientation in matters of economic and social policy development in Africa"... ECA agreed that close and rational co-operation should be promoted within the political bodies and the policy making organs of ECA and the OAU. The ECA submission to the authority of the OAU is then specified as follows:

1. African ministers and senior officials working within the framework of ECA and the OAU Economic and Social Commission are to be "constantly guided by decisions of the Assembly of Heads of State and Government of the OAU in economic and social matters";

2. Reports on the activities of ECA shall be presented regularly for the consideration of the Assembly of Heads of State and Government of the OAU "in order that the Commission might enjoy the necessary political support".

The secretariats of ECA and OAU were also asked "to pursue all forms of desired co-operation in the interest of the development of Africa."

The Administrative Secretary General in his report covering the period from February to September $1970^{24}$ welcomed it as a result of the "determination of the African leaders to keep the initiative and maintain control over any activity carried out in Africa for the sake of Africa" and as he put it "an additional guarantee to the African peoples that ECA's activities will be integrated more harmoniously than in the past into the work of OAU". In the same report the Administrative Secretary General called upon the Assembly of Heads of State and Government to rectify the omission in the OAU Charter concerning the guidelines for specific commitments determining OAU's responsibilities in economic and social matters. This was done by the Resolution on the responsibilities and

22 Resolution on "Africa and UNCTAD III", CM/Res. 158 (XI).

23 E/CN. 14/RES/190 (IX) of 11 February 1969.

$24 \mathrm{CM} / 330$ Part II. 
role of OAU in the economic and social fields adopted by the OAU Summit in Addis Ababa in August in 197025.

The memorandum attached to the resolution set forth the economic and social priorities of the OAU in the following order:

1. Intensification of regional co-operation with a view to defining and carrying out projects of concern to the markets of several countries.

2. Mobilization of domestic financial resources in order to establish African funds in the service of development.

3. Acceleration of the process of industrial development on the continent, with particular emphasis on multinational projects.

4. Increased inter-African trade through improved knowledge of the economic resources and production of each country.

5. Harmonization and co-ordination of legislation and customs procedures.

6. Intensification of monetary co-operation and institution of payments agreements between African States.

7. Promoting the construction of an all-African road network.

8. Co-operation between African air transport companies with a view to increasing trade and promoting tourism.

9. Provision of an all-African telecommunications system

10. Joint utilization of higher educational systems and systems for the training of supervisory staff in the fields of economic and social development.

11. Harmonization of social and labour legislation.

12. Institution of a system of inter-African Technical assistance (exchanges of trained staff and manpower) and

13. Assistance to African non-governmental organizations to help them achieve unity and to associate them with OAU's work.

It should be pointed out, however, that the new arrangement did not alter the fact that ECA was better equipped for dealing with economic problems of African than the OAU. Indeed, while most of the economic programmes, projects and conferences were carried under the joint OAU/ECA sponsorship it was the ECA rather than OAU which did most of the work. However, while the element of competition never really disappeared from the relationship between the two organisations their mutual co-operation has since considerably improved.

At the first meeting of The Conference of Ministers of Economic Commission for Africa at Tunis in February $1971^{26}$ launched "Africa strategy for development in $1970 s^{27}$ " which was based on the programme of priorities adopted by the OAU summit in 1970 and referred to above.

In concrete terms it required African countries to: (a) Develop agriculture-based programmes; (b) Increase export and export earning in order to reduce excessive dependence upon foreign economies for development financing; (c) Develop better and more co-ordinated trade promotion organizations and programmes; (d) Promote labour-intensive industries using local raw materials, wherever they can be competitive in the world market; (e) Promote industrial and agricultural research

\footnotetext{
$25 \mathrm{CM} /$ Res. 219 (XV).

26 The Conference of Ministers, a new body of ECA after its reorganization in 1969 meeting biannually istead of previous annual conferences of ECA.

27 E/CN. 14/Res. $218(\mathrm{X})$ and E/CN. 14/Res. 238 (XI) published as an ECA publication entitled “Africa's Strategy for Development in the 1970s" by ECA in Addis Ababa in November 1973.
} 
and ensure practical application of results; (f) Realign the educational and training systems with the needs and demands of a progressively developing economy and society; (g) Formulate population policies commensurate with the national growth potential23.

The strategy reiterates the previous ECA's emphasies on multinational economic co-operation for which ECA won OAU support. Its instruments are 75 African intergovernmental organisations engaged in various forms of co-operation such as economic communities, common markets, custom unions, co-operation in agriculture, industry, transport and communication, tourism, education, training and research, banking, finance and monetary affairs, plant, animal and human health and natural resources ${ }^{29}$.

The ECA resolution outlining Africa's strategy for development in the 1970s makes it clear that the strategy was worked out in accordance with the programme of priorities for economic and social development of Africa set forth by the OAU Summit in 1970. A more recent joint OAU-ECA contribution to the development strategy of Africa was the "Declaration on Co-operation, Development and Economic Independence" adopted by the African Ministerial Conference on Trade Development and Monetary problems organised jointly by the OAU, ECA and the African Development Bank on 13 May 1973 and endorsed by the OAU Summit on 23 May 1973 at Addis Ababa.

It became a kind of "Economic Charter of the OAU" formulating also Africa's demand for the "New International Economic Order" to be examined in the next section. Unfortunately, not even the joint efforts of the OAU and ECA in the economic field were enough to make their projects work and most of them remained confined to resolutions, reports and recommendations which the OAU members failed to implement partly because of lack of funds and manpower, partly because of lack of political will on their part.

\section{OAU and the New International Economic Order}

The main credit for the initiative in search for a new relationship between the developed and developing countries goes to an African country - Algeria. Since October 1967 when the "African Declaration of Algiers" was adopted in Algiers the capital of Algeria became a venue of several important meetings of similar character. In September 1973 it hosted the Fourth Summit Conference of Non-Aligned Countries, where on 4 September 1974 the Algerian delegation introduced a document entitled "The Third World Countries and the Energy Crisis"33", which drew the attention of the assembled leaders to the changing relationship between the developed countries arising out of the growing dependency of the industrialized countries on the energy and the raw material resources of

28 This is how the requirements were defined by ECA's Executive Secretary, Dr. Robert Gardiner in his address to the Dag Hammarskjöld seminar on a Strategy of Development for Africa, Uppsala, held in August 1971 at Uppsala.

29 For an excellent handbook on African intergovernmental organisation see Directory of Intergovernmental co-operation organisations in Africa" published by ECA in 1972, E/CN/14/CEC/1/Rev. 1 6 June 1972.

30 General Assembly Resolution 3201 (S-VI) and 3202 (S-VI) 1974.

31 General Assembly Resolution 3281 (XXIX) of 12 December 1974.

32 General Assembly Resolution 1897 (XVIII) of 11 November 1963.

33 Document NAC/ALG/CONF. 4/M/L. 18. 
the Third World. "We are at present witnessing a basic reversal in the relative positions of the markets for raw materials and the sources supplying such materials" stated the Algerian document and called it "a new phenomenon in the economic relations between poor and rich countries". What the Algerians were trying to show was that the Third World, of which Africa is the richest part, has in its energy and raw material resources a formidable leverage against the industrial nations and that the time has come to use it. Indeed, a few weeks after, the NonAligned Summit and the countries associated with "The Organisation of the Petroleum Exporting Countries" (OPEC) $)^{34}$ held the Western industrialized countries to ransom. The oil weapon - a combination of price increase of oil with the imposition of embargo on its delivery - was primarily used to exert pressure on the Western supporters of Israel to alter their policy on the Arab-Israeli conflict which erupted in October 1973 in war. However, its disastrous effects on the economies of the Western world confirmed the correctness of the Algerian thesis on the changing relationship between the industrialised and developing countries. The price of crude oil which in October 1973 stood at $\$ 1.25$ per barrel has jumped to $\$ 11.50$ in $1976^{34}$. The oil crisis gave the Third World a new and stronger voice on international relations to which even a superpower such as the United States and economic giants such as the Federal Republic of Germany and Japan were forced to listen. Thus the call for a new pattern of international economic relations was at last taken seriously and ways and means how this was to be achieved was a topic of a number of international conferences and meetings.

At the United Nations level the most important meetings were the two Special Sessions of the General Assembly on 9 April - 2 May 1974 the 6th Special Session of the General Assembly of the United Nations which adopted the above mentioned Declaration and Programme of Action on the Establishment of a New International Economic Order. The other was the 7th Special Session of the UN General Assembly convened from 1 to 12 September to discuss "Development and International Co-operation" which adopted a resolution dealing with international trade, transfer of real resources for financing the development of developing countries and international monetary reforms, science and technology, industrialization, food and agriculture, co-operation among developing countries and on restructuring the economic and social sections of the United Nations ${ }^{\mathbf{3 5}}$.

The New International Economic Order, the essence of which was simply "full and complete emancipation of developing countries", was discussed also at a conference of 110 developing countries in Dakar in February 197536, at the Fifth Ministerial Conference of Non-Aligned Countries in Lima in August $1975^{37}$ and at the Second General Conference of the United Nations Industrial Development Organisation (UNIDO) in March 197538.

\footnotetext{
34 The Organization of the Petroleum Exporting Countries (OPEC) was established 1960 "to unify and co-ordinate members' petroleum policies and to safeguard their interests generally". Its members are Algeria, Ecuador, Indonesia, Iran, Irag, Kuwait, Libya, Nigeria, Qatar, Saudi Arabia, United Arab Emirates, Venezuela and Gabon (associate member).

35 Emirates, Venezuela and Gabon (associate member). 3362 (S-VII) on "Development and international economic co-operation of 16 September 1975.

36 Raw materials were the main topic of the Dakar Conference the aim of which was to discuss a common strategy (outlined in the Dakar Declaration) of developing countries for the UNCTAD meeting at Geneva which was held a week later.

37 For the proceedings of the Lima Conference (and for the full text of all resolutions) see Review of International Affairs, Belgrade, No. 611 and 612 (September 21 and October 51975 ).

38 Lima Declaration and Plan of Action on Industrial Development Co-operation was published as a UN Document A/10217.
} 
Although members of the Organisation of African Unity actively participated in all these conferences the role of OAU as an organisation was marginal. It refrained itself to the support of African initiative led by the Economic Commission for Africa and to ECA's "African Plan for the Implementation of the Programme of Action on the Establishment of a New International Economic Order" adopted at the Third Conference of Ministers of ECA in Nairobi in February $1975^{39}$.

The best example of OAU's attitude is the OAU resolution on the New International Economic Order submitted by the Council of Ministers to the OAU Summit in Kampala in July $1975^{40}$, which shifts the responsibility on to the United Nations and the Non-Aligned Countries. OAU's decision to convene a meeting of experts of the OAU, ECA, the African Development Bank and the Institute for Development and Planning to formulate an African position at the forthcoming meetings dealing with the New International Economic Order can hardly be called an "adequate OAU initiative“.

When the 20th Commonwealth Conference of 33 countries, held in Kingston in April 1975, agreed to the six commitments set out later in a report, "Towards a New International Economic Order", this was due more to British initiative than to the African members of the Commonwealth ${ }^{41}$.

Africa's best achievement so far in its effort for a more just economic relationship with developed countries was the signing of the Lomé Convention on 28 February 1975 by 46 African and Caribbean and Pacific countries with the nine countries of EEC after 18 months of tough negotiations. The Lomé Convention represents a major concession obtained by Africa from the European community ${ }^{42}$.

At the 7th Special Session of the General Assembly of the United Nations African delegates showed awareness of the acute economic problems facing the African continent and put forward a number of constructive proposals ${ }^{43}$. At the same time it became apparent that Africa as a whole still lacks the kind of economic unity needed for effective participation in shaping the economic future of the African continent.

By the end of 1975 appeared encouraging signs of the efforts to involve OAU more deeply into the economic problems of the continent.

39 Res. 256 (XII).

$40 \mathrm{CM} /$ Res. $437^{\circ}$ (XXV) "Resolution on the New International Economic Order and the Forthcoming Special Session of the General Assembly".

41 The key note of the Commonwealth approach was the British Prime Minister Harold Wilson's opening statement that "The British Government fully accepts that the relationship, the balance, between rich and poor countries is wrong and must be remedied. That is the principle on which my proposal rests: that the wealth of the world must be redistributed in favour of the povertystricken and of the starving". The six commitments agreed upon by the conference were as follows:

1. To recognise the desirability of conducting trade in food and raw materials in accordance with equitable arrangements worked out in agreement between producers and consumers.

2. Producer countries should undertake to maintain adequate and secure supplies to consumer countries.

3. Consumer countries should undertake to improve access to markets for primary products of interest to producers in developing countries.

4. As an established principle, commodity pirces should be equitable to consumers and remunerative to efficient producers.

5. In particular, the need to expand total production of essential foodstuffs should be recognised

6. The aim should be to encourage the efficient development, production and marketing of commodities both mineral and agricultural, including forest products, and efficient processing of those commodities in developing countries.

42 The convention which covers all of independent black Africa, most of the Carribbean and three Commonwealth Pacific islands, Fiji, Samoa and Tonga. The agreement provides the developing countries with privileged access to the EEC for all their exports, with a stabilization fund to compensate the developing countries for any fall in market prices of a number of basic products, financial aid amounting to $\$ 4,068$ million over five years, better distribution of labour in favour of developing countries through industrial co-operation.

43 For a selection of the main points of the speeches of 10 African delegates see Africa, London, No. 52, 2 December, 1975. 
The OAU sponsored (jointly with ECA and UNIDO) the Third Conference of the African Ministers of Industry held in December at Nairobi. The conference, attended by 27 OAU members set the target of raising Africa's share of the world's industrial output from the present 0,6 to 2,0 by the year 2000. The African ministers also agreed to establish an African center for design, adaptation and transfer of industrial technology and a regional industrial plant design and construction center. But perhaps most important was the decision to set up a follow-up Commitee with a direct link to the Assembly of Heads of State and Government in order to impress upon the African leaders the necessity of dealing also with the economic issues.

Similar trend was in evidence at the Fourth Conference of African Trade Ministers held in Algiers in November 1975. It discussed inter-African co-operation and the expansion of African trade as well as "Measures to accelerate political decolonization and economic liberation of the African continent". It was decided to institutionalize the Conference by making it a special OAU Commission and to set up an African Trade and Development Organization. Both proposals were approved by the OAU 13th Summit held in July 1976 at Port Louis, Mauritius.

\section{Africa and the North-South dialogue}

In the negotiation between the industrialized countries Africa became a mere apendage of OPEC hoping to benefit from the deal OPEC might succeed to negotiate. This situation has developed despite the efforts of Algeria to broaden the base of negotiations beyond the issue of energy sources which the United States, Western Germany and other Western powers (except France) wished to single out ${ }^{44}$. As many times before Algeria again assumed the role of the spokesman of Africa at the Paris International Conference on Economic Cooperation held in December 1975 and called "the North-South dialogue 45". The conference revealed that the gulf of differences between the developing and industrial countries had not been narrowed, on the contrary it had widened. To make things even worse the mutual distrust which characterizes the present relationship between rich and poor nations had slowly been creeping into the ranks of the Third World. Algeria introduced its proposal for "indexing of all raw material prices". In the terms of world trade this means relating the price of raw materials to the price of commodities exported by industrial countries. Whenever the industrialized countries increase their prices so will the raw material producers. The industrialized countries want nothing of the sort. Soon the North-South dialogue turned again into confrontation between the oil producers and oil consumers. The absence of any other agreement but to keep talking was covered up by the creation of four commissions - on energy, raw materials,

\footnotetext{
44 For a most comprehensive document on Algerian policy on the New International Economic Order see "Petroleum, raw materials and development" a memorandum submitted by Algeria to the 6th Special Session of the United Nations General Assembly, published on 10 April 1974 by SONTRACH, Algiers.

45 The developing countries within their Group of 77 , selected the following participants: Brazil, Argentina, Peru, Mexico, Jamaica, Venezuela, Algeria, Zaire, Egypt, Nigeria, Zambia, Cameroon, India, Iran Iraq, Indonesia, Pakistan, Saudi Arabia and Yugoslavia. They also proposed that the Conference be expanded with the participation of Malaysia, the Ivory Coast, and Columbia. The industrially developed Western countries in the OECD selected Japan, USA, EEC, Canada, Sweden, Switzerland, Spain and Australia.
} 
developing assistance and international finance ${ }^{46}$. The commissions began their work in January 1976.

The exclusion of black Africa from the chairmanship of any of the four commissions illustrates the weakness of African position in the negotiations about the New International Economic Order. Indeed, the voice of Africa in Paris was, apart from that of Algeria, was lamentably small. Algerian chairmanship of the commission on the development assistance (secondary in importance to those on energy and raw materials) cannot be regarded satisfactory from several reasons. Though Algeria has a fine record of working hard for the meaningful relationship between the Arabs and African a number of African countries are beginning to have a second thought on whether their interests are best served by countries belonging to such an exclusive club as the organisation of the Petroleum Exporting Countries. It is also a common knowledge that Algerian initiative in OPEC is being blocked by countries like Iran, South Africa's largest supplier of oil and the one which has been deaf to African pleas to impose blockade on the white minority regimes in Southern Africa, and by Saudi Arabia whose interests (especially financial) are closer to those of the United States than to those of Africa. The conspicious silence of Nigeria and Gabon, the only black African OPEC members, added to the doubts about OPEC's attitude towards the necessity of aleviating the burden of African oil importers.

Most African countries find themselves between two crushing pressures: one originating in the high oil prices, the other in the inflation in the Western world which is now being steadily imported into their economies. President Julius Nyerere of Tanzania put it in his address to the Royal Commonwealth Society in London in November 1975 as follows:

"But rich countries do not only increase the price of a tractor to the extent of the extra oil costs directly involved in producing it. They also make the new price compensate the workers and the owners for the higher oil prices involved in producing the goods which they want to consume. For the workers in wealthy countries get 'cost of living' increases to prevent their standard of living from falling. And the owners seek to arrange that their profits should not go down in real terms. Both these costs are covered by additions to the price of the goods they sell. As a result we do not only pay from our poverty for the extra wealth acquired from us by the oil producers. We also compensate the people in the wealthy countries for any loss which they experienced through a transfer of wealth from their economies to the oil producers."

The African countries find little comfort in the North-South dialogue which is still dominated by the controversies about oil prices to which they are only bystanders. They do not see much attraction in the probable deal between the

\footnotetext{
46 The energy commission is co-chaired by the United States and Saudi Arabia. Its members are Argentina, Brazil, Egypt, India, Iran, Iraq, Jamaica, Venezuela, Zaire, Canada, the EEC, Japan and Switzerland.

The raw materials commission is co-chaired by Peru and Japan and its members are Argentina, Cameroon, India, Yugoslavia, Mexico, Nigeria, Venezuela, Zaire, Zambia, Australia, EEC, Spain and the United States.

Development assistance commission is presided by Algeria and the EEC and its members are Argentina, Cameroon, India, Iran, Yugoslavia, Nigeria, Mexico, Pakistan, Peru, Canada, Japan, Sweden and the United States.

Finally, the finance commission is co-chaired by Iran and the EEC and its members are Brazil, Egypt, Indonesia, India, Iraq, Mexico, Pakistan, Saudi Arabia, Zambia, Japan, Switzerland, Sweden and the United States.
} 
oil producers and oil consumers by which the consent of the industrialized countries to the elements of the New International Economic Order is to be secured by an OPEC promise to stabilize the price of oil and maintain its supply. They fear that any such deal would undoubtedly work out in order to meet first of all the interest of the parties most concerned - OPEC on one hand and the industrialized on the other. The demands of the countries not belonging to any of the two power blocks would always be easiest to dismiss.

The strenght of Africa lies not only in the unity of action of OAU members, their self-reliance, mutual economic co-operation in full control of their enormous natural resources, but also by recognizing the necessity for alterations in the concept of their own economic development. The priority to national interests over those of Africa as a whole is the main African weakness in its relations with the Western countries. To provide Africa with economic leadership was regarded by many as one of the most important tasks of the OAU in its second decade.

After 13 years of the existence of OAU the real struggle for the liberation of the Continent of Africa from the economic domination by the outside powers has hardly begun. 
and the domestic economy, as public enterprises have increasingly emerged as the main forms of joint ventures. Many public enterprises are this forms for at least partially private investment.

The paper also examines the relationship between public enterprises and the national economic plan. It looks at the case of grants of wider and wider discretionary powers to bureaucrats and administrators, and suggests some implications of this on the legal system, which is traditionally conceived in terms of rules and standards. Finally the paper suggests the various ways in which the emergence of public enterprise has affected the legal system, and the effect the legal system has had on public enterprise. There have been few systematic studies of the subject, so that our knowledge is patchy and superficial. As public enterprise becomes one of the major institutions for industry, finance and commerce, and as it increases in importance in political and constitutional terms, the regulation of it by and its accommodation within, the legal system becomes an urgent question, calling for intelligent research in this area.

\section{Africa and the New International Economic Order}

\section{By Zdenek Cervenka}

The article begins with examining the reasons for why the Organization of African Unity had been paying little attention to the economic problems of Africa despite the fact that it had been originally intended to provide a basis for inter-African co-operation in the economic field. Using the East African Economic Community as an example, the author concludes that no meaningful economic co-operation is possible in the absence of political unity of all partners involved.

A section on the relationship between OAU and ECA (Economic Commission for Africa) describes the competition between the two organisations, for economic leadership in Africa. While OAU succeeded in winning recognition for being "primarily responsible", it was the ECA which still did most of the work. The second part of the article gives a background to the rise in demand for the New International Economic Order, the main credit for which goes to Algeria and mentions the recent major conferences devoted to it. The author dwells in more detail on the North-South Dialogue currently continuing in Paris and concludes that the dialogue has so far been dominated by the oil-producing countries on the hand and the industriealized consumers on the other, with Africa playing the role of outsider.

The author concludes that after the 13 years of OAU's existence, the real struggle for the liberation of Africa from the external economic domination has hardly begun. 